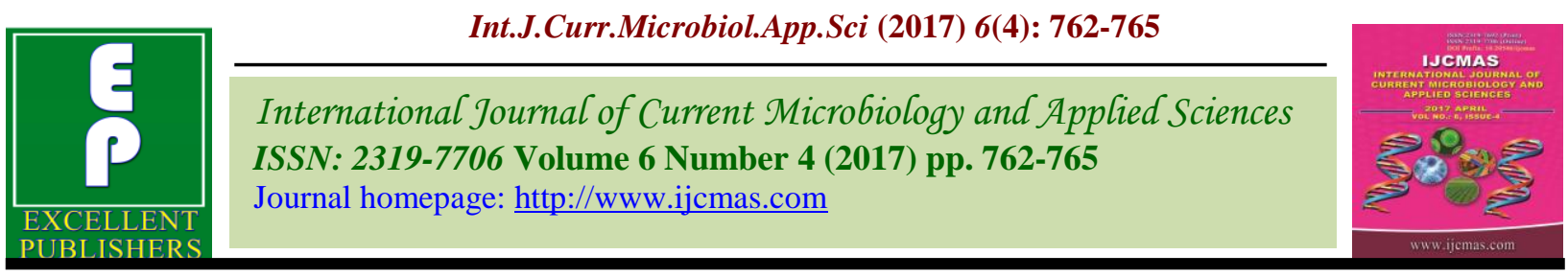

Original Research Article

https://doi.org/10.20546/ijcmas.2017.604.094

Nasal Granuloma in Buffalo: An Unusual Case of Actinomycosis

\author{
Gauri A. Chandratre ${ }^{1}$, Renu Singh ${ }^{1}$, Sandeep Saharan ${ }^{2}$, \\ Satbir Sharma ${ }^{2}$ and Adya Prakash Rath ${ }^{3}$
}

\author{
${ }^{1}$ Department of Veterinary Pathology, Lala Lajpat Rai University of Veterinary and Animal \\ Sciences (LUVAS), Hisar, Haryana, India \\ ${ }^{2}$ Department of Veterinary Surgery and Radiology, Lala Lajpat Rai University of \\ Veterinary and Animal Sciences (LUVAS), Hisar, Haryana, India \\ ${ }^{3}$ National Research Centre on Equines, Hisar, India \\ *Corresponding author
}

\begin{tabular}{|c|c|}
\hline & A B S T R A C T \\
\hline $\begin{array}{l}\text { Actinomycosis, } \\
\text { Growth in nostril, } \\
\text { Gram stain, } \\
\text { Cytology, Buffalo. }\end{array}$ & \multirow{3}{*}{$\begin{array}{l}\text { A 3-year-old buffalo with a history of } 3 \text { months old proliferative overgrowth in the left } \\
\text { nostril occluding whole nostril was presented in Teaching Veterinary Clinical Complex. } \\
\text { There was laboured breathing; however, the clinical parameters were found within normal } \\
\text { range. The growth was removed surgically and tissue was processed for cytology and } \\
\text { histopathology. Grossly, the cut surface of the growth appeared "creamish white with } \\
\text { multifocal pale yellow areas of calcification." Impression smear revealed abundant } \\
\text { neutrophils and macrophages engulfing bacteria. Gram staining revealed gram positive } \\
\text { branching filamentous organism. Microscopically, multiple granulomas were observed } \\
\text { with "the presence of bacterial colonies and club-shaped product surrounded by strong } \\
\text { neutrophilic reaction." On the basis of clinical sign, cytology, gram staining of impression } \\
\text { smears and histopathology, it was diagnosed as a case of actinomycosis. }\end{array}$} \\
\hline Article Info & \\
\hline $\begin{array}{l}\text { Accepted: } \\
\text { 06 March } 2017 \\
\text { Available Online: } \\
10 \text { April } 2017\end{array}$ & \\
\hline
\end{tabular}

\title{
Introduction
}

Actinomycosis is a subacute-to-chronic bacterial infection caused by filamentous, gram positive, anaerobic to microaerophilic bacteria that are not acid fast. Although they are normal flora of the oral and nasopharyngeal membranes, several species are associated with diseases in animals. Actinomycosis is a specific disease characterized by a classical rarefying mandibular osteomyelitis and commonly known as "lumpy jaw" in cattle caused by Actinomyces bovis. These organisms are obligatory parasites of the oropharynx in most of the animals and therefore lesions mainly occur in adjacent tissues of the cervicofacial region (Masand et al., 2015). Mucosal injury is an essential prerequisite for establishment of infection by the organisms. It is further characterized by contiguous spread, suppurative and granulomatous inflammatory reaction, and formation of multiple abscesses and sinus tracts that discharge sulphur granules. Involvement of adjacent bone frequently results in facial distortion, loose teeth (making chewing difficult), and dyspnea from swelling into the nasal cavity (Radostits et al., 2007). Nasal actinomycosis is a rare clinical disease. It can occur after nasal trauma or surgical manipulation. It is also reported to occur without prior trauma, 
making diagnosis difficult. This short communication describes the clinical, pathomorphological findings, and the surgical treatment of a case of an atypical nasal actinomycosis in a Buffalo.

\section{History and observations}

A 3-year-old Buffalo with a history of 3 months old proliferative overgrowth increasing in size in the left nostril was presented in Teaching Veterinary Clinical Complex, LUVAS, Hisar. Clinical examination demonstrated a snoring-like noise in the inspiratory phase, extended head and neck position, exaggerated abdominal effort and a dense, whitish mucous-like bilateral nasal discharge. Hematobiochemical analyses were unremarkable. The mass was surgically removed for which the animal was sedated with xylazine (Inj. Xylaxin, Indian Immunologicals Ltd.) intravenously followed by local infiltration of $2 \%$ lignocaine @ 0.05 $\mathrm{mg} / \mathrm{kg}$ b. wt. hydrochloride (Inj. Lox, Neon Laboratories Ltd.). Post operatively, inj. ceftrioxone (Inj. Zydacef, Zydus India Ltd.) 4 gm, ketoprofen (Inj. Vetoprofen, Merial India Ltd.) $20 \mathrm{ml}$ and chlorphenarmine maleate (Inj. Avilin, Merial India Ltd.) were administered intramuscularly for five consecutive days. Antiseptic dressing was done using povidone iodine for seven days and skin sutures were removed on 10th post operative day.

\section{Materials and Methods}

After removal of growth, tissue was processed for cytology and histopathology. Cell cytology was carried out with the help of impression smears stained with Field's stain. Impression smears were taken from cut surface of tissue on a clean glass slide and dried in air. Fixation was done in methanol for two minutes and air-dried. After that, fixed smear was dipped into Field Stain B
(Red Stain) for 30 seconds and it was washed with running tap water. Again that smear was dipped into Field Stain A (Blue Stain) for 2030 seconds and washed with running tap water. It was air-dried and seen under oil immersion microscope. Impression smear was also stained with Gram Stain for differentiation of bacteria. Representative tissue was collected in $10 \%$ buffered formalin for histopathological studies. After proper fixation, tissues were cut into small sections with thickness of 2-3 $\mathrm{mm}$ and washed overnight in running tap water. After removal of fixative, the tissues were dehydrated in ascending grades of alcohol, cleared in benzene and embedded in paraffin blocks. The paraffin embedded tissues were cut into 4-5 $\mu$ thick section and stained with Haematoxylin and Eosin (Luna, 1968).

\section{Results and Discussion}

Actinomycosis is very common in occurrence but nasal actinomycosis in buffalo is very rare. Only a few cases have been published (Masand et al., 2015). In the present case, gross examination revealed a granulomatous mass occluding the entire nostril (Figure 1A). Grossly, the cut surface of the growth appeared "creamish white containing thick pus with multifocal pale yellow areas of calcification (Figure 1B)". Impression smear stained with Field Stain revealed abundant neutrophils (Figure 1C) and macrophages (Figure 1D) engulfing bacteria. Gram staining revealed purple-coloured gram positive branching filamentous organism (Figure 2A). Histopathological examination revealed multiple granulomas with radiating colonies of bacteria (Figure 2B). The radiating bacterial colonies were surrounded by strong zone of neutrophillic reaction (Figure 2C). Club-shaped bacterial colony observed which characteristic feature of actinomycosis. 
Fig.1 A: Granulomatous mass occluding the entire nostril entire nostril. B: Grossly, the cut surface of the growth showing "creamish white thick pus with multifocal pale yellow areas of calcification. C: Impression smear stained with Field Stain showing abundant neutrophils D: macrophages engulfing bacteria

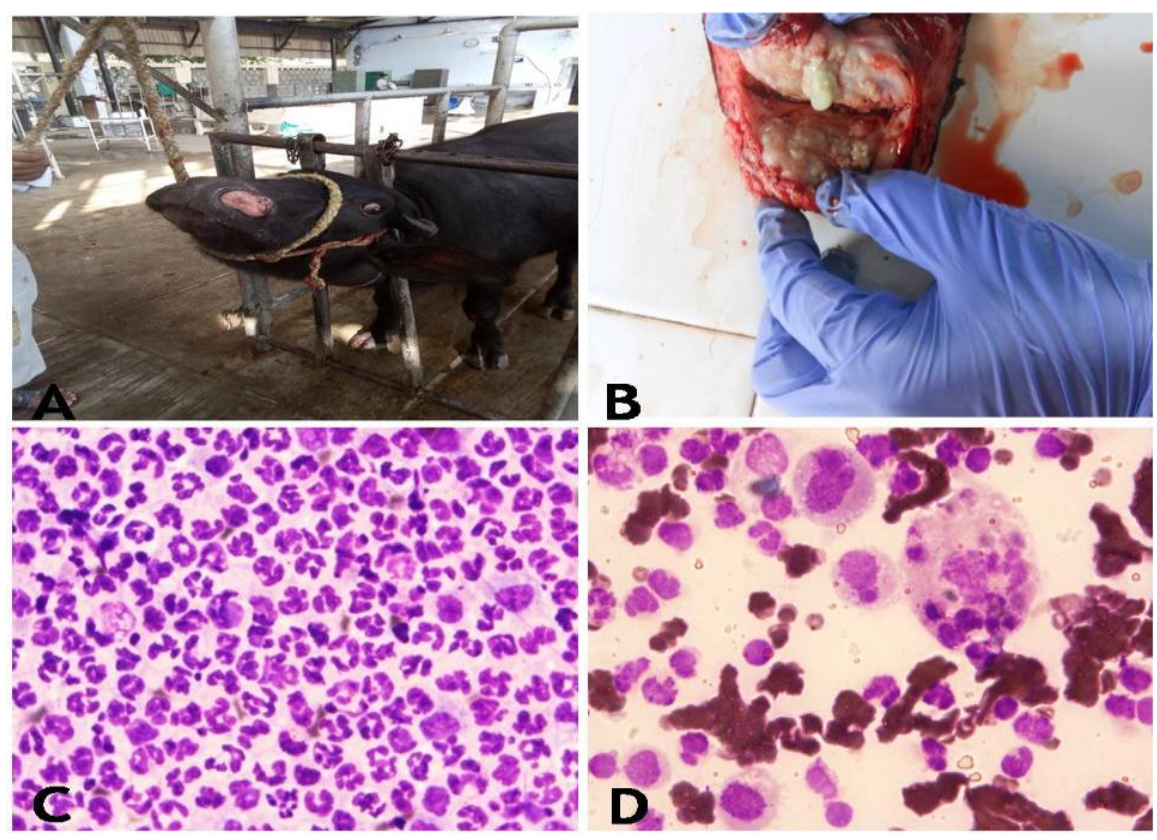

Fig.2 A: Gram staining showing purple-coloured gram positive branching filamentous organism (arrow) B: Tissue section showing multiple granulomas with radiating colonies of bacteria (arrow; H \& E stain 200x). C: The radiating bacterial colonies were surrounded by strong zone of neutrophillic reaction (H \& E stain 400x)

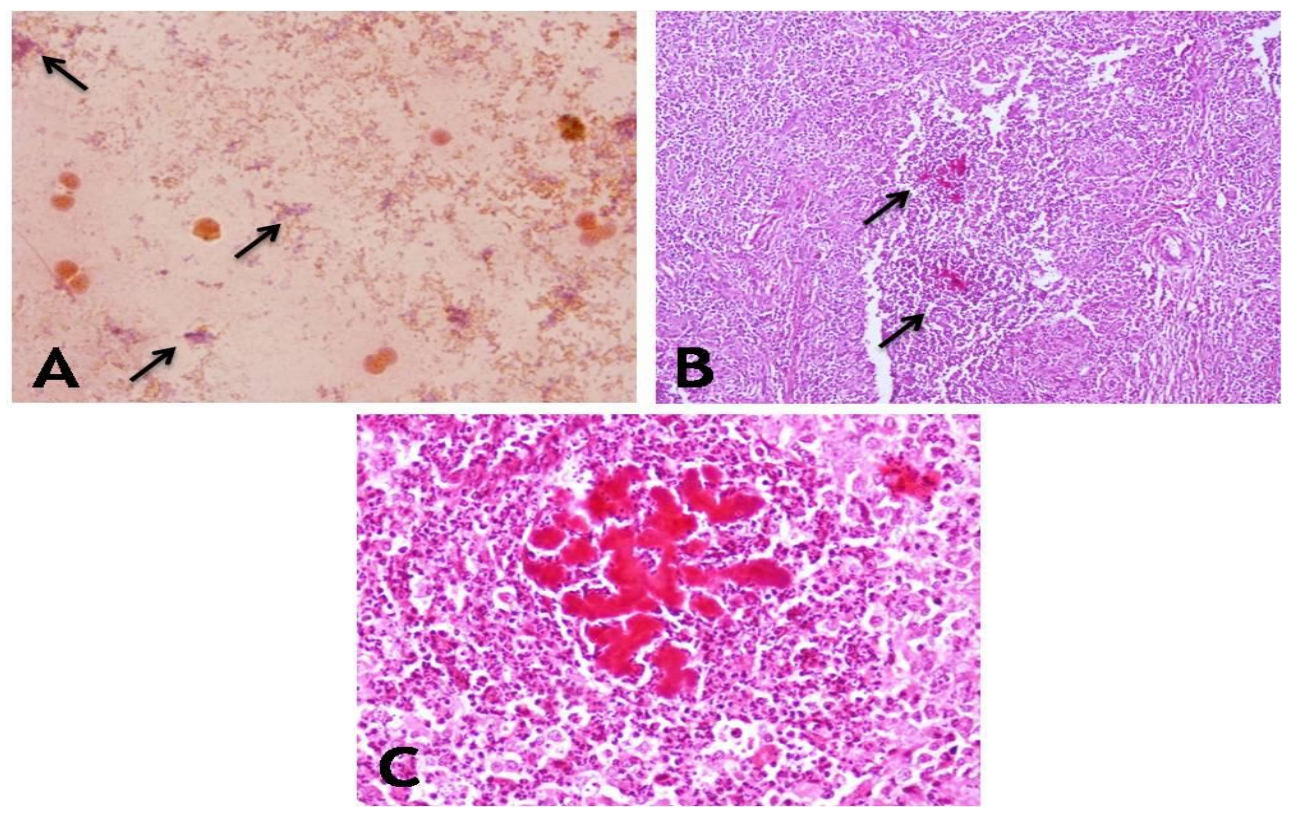


The clinical signs, gross and histopathological observations in the present study were similar to the previously described pathology (Nashiruddullah et al., 2004; Farooq et al., 2013). Although Actinomyces species are Gram positive, non spore forming rods or filaments, they often stain irregularly, giving rise to a beaded appearance (Masand et al., 2010) as observed in this study. Occasional macrophages and absence of giant cell may indicate the relative immature form of the lesions in the present case however a massive accumulation of polymorphonuclear cells may be due to a strong chemotaxis for these cells. In the present case, animal was uneventfully recovered. The present case explore that nasal Actinomycosis is one of the important disease condition affecting respiratory system whose occurrence should be evaluated in buffalo.

\section{References}

Farooq, U., A. Qayyum, H.A. Samad, H.R.
Chaudhry and N. Ahmad. 2013. Field surgical intervention of bovine actinomycosis. Pak. Vet. J., 8318: 2074-7764.

Luna, L.G. 1968. Manual of histologic staining methods of the Armed Forces Institute of Pathology. (3rd edn.), Mc Graw Hill Book Company, New York.

Masand, A., N. Kumar and V. Patial. 2015. Actinomycosis (lumpy jaw) in cow: a case report. Comp. Clin. Pathol., 24: 541-543.

Nashiruddullah, N., M.M. Darzi, S.A. Kamil. M.S., Mir and F. Peer. 2004. Comparative efficacy of fine needle aspiration and incisional biopsies in the diagnosis of bovine actinomycosis. Vet. Arh., 74(6): 443-452.

Radositis, O.M., C.C. Gay., K.W. Hinchcliff and P.D. Constable. 2007. Veterinary Medicine: A Textbook of the Diseases of Cattle, Sheep, Pigs, Goats and Horses. 10th ed., Saunders Elsevier, Spain, 1045-1046.

\section{How to cite this article:}

Gauri A. Chandratre, Renu Singh, Sandeep Saharan, Satbir Sharma and Adya Prakash Rath. 2017. Nasal Granuloma in Buffalo: an unusual case of Actinomycosis. Int.J.Curr.Microbiol.App.Sci. 6(4): 762-765. doi: https://doi.org/10.20546/ijcmas.2017.604.094 